\title{
Gene-signatures predict biologically relevant dose-response potencies in phenotypic assays
}

Steffen Renner ${ }^{1^{*}}$, Christian Bergsdorf ${ }^{1}$, Rochdi Bouhelal ${ }^{1}$, Magdalena Koziczak-Holbro², Andrea Marco Amati ${ }^{1}, 6$, Valerie Techer-Etienne ${ }^{1}$, Ludivine Flotte ${ }^{2}$, Nicole Reymann ${ }^{1}$, Karen Kapur ${ }^{3}$, Sebastian Hoersch ${ }^{3}$, Edward J. Oakeley ${ }^{4}$, Ansgar Schuffenhauer ${ }^{1}$, Hanspeter Gubler ${ }^{3}$, Eugen Lounkine ${ }^{5}$, Pierre Farmer ${ }^{*}$

1 Chemical Biology \& Therapeutics, Novartis Institutes for Biomedical Research, Basel 4056, Switzerland

2 Musculoskeletal, NIBR, Basel, Switzerland

3 NIBR Informatics, NIBR, Basel, Switzerland

4 ASI, NIBR, Basel, Switzerland

5 Chemical Biology \& Therapeutics, NIBR, 181 Massachusetts Avenue, Cambridge, MA 02139, USA

6 current address: Department of Chemistry \& Biochemistry, University of Bern, Freiestrasse 3, 3012 Bern, Switzerland

* Corresponding authors:

Steffen Renner: steffen.renner@novartis.com

Pierre Farmer: pierre.farmer@novartis.com

\section{Abstract}

Multiplexed gene-signature-based phenotypic assays are increasingly used for the identification and profiling of small molecule-tool compounds and drugs. Here we introduce a method (provided as Rpackage) for the quantification of the dose-response potency of a gene-signature as $\mathrm{EC}_{50}$ and $\mathrm{IC}_{50}$ values.

Two signaling pathways were used as models to validate our methods: beta-adrenergic agonistic activity on CAMP generation (dedicated dataset generated for this study) and EGFR inhibitory effect on cancer cell viability. In both cases, potencies derived from multi-gene expression data were highly correlated with orthogonal potencies derived from CAMP and cell growth readouts, and superior to potencies derived from single individual genes.

Our results show that gene-signature potencies are a novel valid alternative to conventional readouts for compound potency quantification, in particular in scenarios where no other established readouts are available. 


\section{Introduction}

Gene expression signatures are widely used in the field of translational medicine to define disease subtypes [1], severity [2] and predict treatment outcome [3]. Bridging this technology to early drug discovery was previously proposed years ago $[4,5]$ but its prohibitive costs limited this approach. The recent advancement of massively parallel gene expression technologies such as RASL-seq [6], DRUG-seq [7], QIAseq [8, 9], PLATE-seq [10], or LINCS L1000 [11] are now transforming the field of compound profiling, enabling larger scale profiling and screening experiments at a more affordable cost [12-17].

In drug discovery, dose-response experiments enable researchers to compare the efficacy of various compounds to modulate biological processes of interest, finding doses for animal and human experiments and estimating windows to off-target and toxic effects. Multiple statistical methods are reported for the identification of individual genes with a dose dependent effect from dose-response gene expression data [18-23]. However, in the case of multivariate gene expression profiling there are no generally accepted methods to estimate the key pharmacological efficacy variables $\mathrm{EC}_{50}$ (compound concentration of halfmaximal activating effect) and $\mathrm{IC}_{50}$ (compound concentration of half-maximal inhibitory effect) from multiparametric readouts.

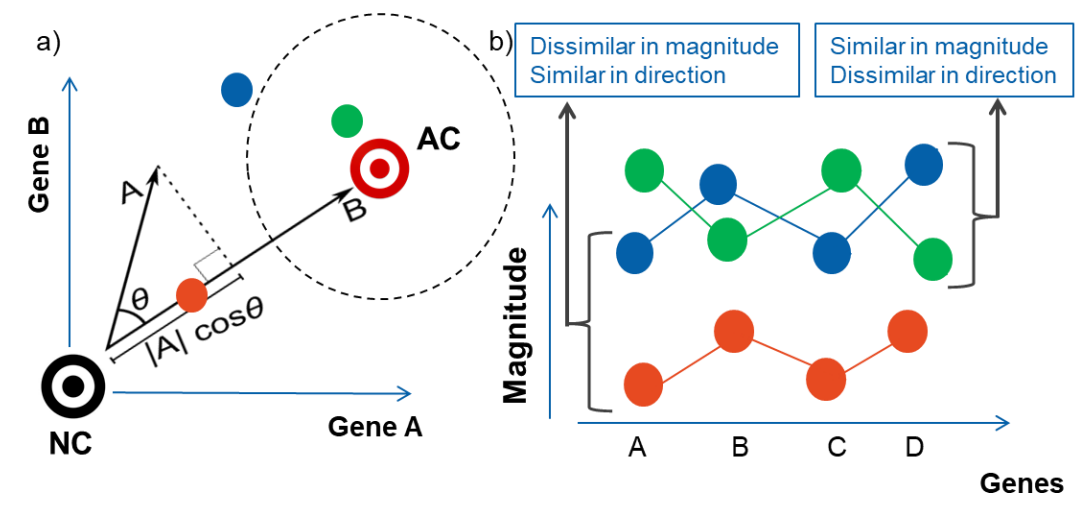

Figure 1. Introduction to gene-signature quantification methods. a) Within the manuscript, we consider methods measuring the similarity of gene-signature changes relative to an active control (AC) or a neutral control (NC). b) Two main characteristics of signature similarity can be distinguished: similar changes in magnitude or similar changes in the direction of the gene expression. The magnitude can be interpreted biologically as the efficacy, while the direction emphasizes the direction of the change of the phenotype, e.g. different pathways might result in different directions of changes in gene expression.

Connectivity Map (CMap) established the concept that compounds with similar mode of actions (MOAs) are highly similar in their differential expression profiles over many genes [4, 11, 24]. We postulate that this concept can be applied for quantifying compound potencies based on compound/pathway specific gene expression signatures. This work aims at defining and comparing several multivariate statistical summaries to enable classical compound potency estimation. In this study, we focus mainly on methods measuring the similarity of gene-signature changes relative to a gene-signature induced by an active control compound, representing a defined phenotype of interest, e.g. a tool compound for a target or pathway of interest. The overall principal relies on assessing the similarity of a compound-induced genesignature profile relative to the one generated by an active control compound; hence, the AC profile will anchor all other measurements in the form of a global reference.

The different similarity methods explored in this paper differ by their approach to assess either the direction of the effect (as example by the geometric angle (cosine) to the AC; referred as direction-based 
methods) and / or by how the magnitude of the effect is assessed (e.g. Euclidean distance to the NC, referred as magnitude-based methods). Combined, the two measures quantify the strength and direction of a phenotypic effect (see Fig. 1 and Table 1). Methods referred to as direction\&magnitude-based combine both types of information into a single measure.

Table 1: Overview over gene-signature quantification methods.

\begin{tabular}{|c|c|c|}
\hline Method & Description & Method class \\
\hline cor_p_AC & $\begin{array}{l}\text { Pearson correlation of the compound signature to the active control } \\
\text { signature }\end{array}$ & direction \\
\hline cor_s_AC & $\begin{array}{l}\text { Spearman rank correlation of the compound signature to the active control } \\
\text { signature }\end{array}$ & direction \\
\hline cos_AC & Cosine of the compound signature to the active control signature & direction \\
\hline cos_weight_AC & $\begin{array}{l}\text { Cos_AC * significance_weight. } \\
\text { Idea: downweight cosine values for signatures with very small / non- } \\
\text { significant amplitudes, likely caused by noise. } \\
\text { Significance weight = weight from } 0 \text { to } 1 \text { quantifying the significance of the } \\
\text { signal amplitude of the compound gene-signature vector. Formula: } \\
\text { min( } 1 \text {, mean(abs(gene rscores)) } / 3 \text { ). The mean of the absolute gene } \\
\text { expression value rscores of the signature readouts divided by } 3 \text { equals } 1 \text {, if } \\
\text { on average the rscores of the signature are } 3 \text { standard deviations away from } \\
\text { the background. This is considered the threshold from where on signals are } \\
\text { considered strong enough not to be downweighted. This score requires the } \\
\text { gene expression readouts to be scaled as rscores. }\end{array}$ & direction \\
\hline dot_p_AC & Dot product of compound signature with the active control signature & direction\&magnitude \\
\hline scalar_projection_AC & Scalar projection of the signature to the active control signature & direction\&magnitude \\
\hline vec_norm & Norm of the compound signature vector & magnitude \\
\hline euc_NC & Euclidean distance of compound signature from neutral control signature & magnitude \\
\hline maha_NC & $\begin{array}{l}\text { Mahalanobis distance of the compound signature from the neutral control } \\
\text { signature }\end{array}$ & magnitude \\
\hline num_readouts_changed & Number of readouts with signal different from background (abs(rscore) $>3$ ) & magnitude \\
\hline euc_AC & Euclidean distance of the compound signature to the active control signature & AC_similarity \\
\hline maha_AC & $\begin{array}{l}\text { Mahalanobis distance of the compounds signature to the active control } \\
\text { signature }\end{array}$ & AC_similarity \\
\hline
\end{tabular}

For this study, two well-characterized biological pathways with multiple well-characterized ligands were selected: the beta-adrenergic receptor pathway for which we generated experimental biological data for this manuscript, and the EGFR pathway, which is publicly available through the LINCS L1000 project [11].

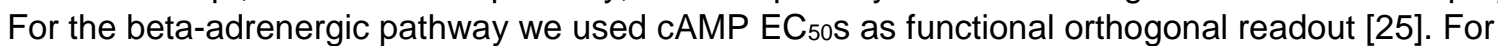
practical purposes, we had to measure a small set of biologically relevant genes, instead of the full transcriptome like in CMap. RNA-seq was used to determine a beta-adrenergic receptor specific genesignature that was subsequently used to quantify compound potencies on the level of gene expression. The L1000 assay is a panel of ca. 1000 measured genes, which are used to infer the differential gene expression of a total of ca. 13k genes. This allowed us to benchmark our methods using all L1000 genes, and subsets thereof specific for EGFR signaling or cell proliferation. The $\mathrm{IC}_{50} \mathrm{~S}$ calculated from gene expression were compared to compound potencies measuring the inhibition of cell growth rate $\left(\mathrm{GR}_{50}\right)$ [26].

Our results demonstrate that gene-signature-based compound $\mathrm{EC}_{50}$ and $\mathrm{IC}_{50}$ values estimated with multivariate gene-signatures are highly related to potencies inferred with relevant but independent reference readouts. Therefore, we expect that these methods will find a wide application in gene-signature based assays in the near future. All methods in Table 1 and an $\mathrm{EC}_{50}$ and $\mathrm{IC}_{50}$ fitting method are made available in the R-package mvAC50 on github [https://github.com/Novartis/mvAC50]. 
Results

\section{Generation of the beta-adrenergic receptor dataset}

Vitamin-D3 differentiated THP1 cells were chosen as an experimental model for its sensitivity to beta agonists over a large dynamic range of compound concentrations and the ease of measuring cAMP [27]. To identify a gene-signature for beta agonists, a series of RNA-seq experiments were performed on THP1 cells sampled at baseline and after four hours stimulation with adrenaline, noradrenaline or isoproterenol.

Genes differentially expressed over all three treatments were identified, and prioritized for large fold change and high expression levels, for independent qPCR validation (Supplementary Fig. 1a). Our internal compound screening setup allows us to simultaneously multiplex the measurement of eight genes. Two independent sets of seven genes were defined from $14 \mathrm{gPCR}$ validated genes

(Supplementary Table 1, Supplementary Fig. 1b) with the eighth gene per set (TBP) serving as a baseline house keeper gene. For our analysis, we considered the two sets of genes as two independant signatures. Not all of these 14 identified genes produced a detectable signal in the QuantiGene Plex technology due to decreased sensitivity of this method compared to qPCR (Supplementary Fig. 1b). The two sets of genes contain respectively three (CD55, DOCK4, and NR4A1) and five genes (PDE4B, SGK1, THBS1, TOB1 and VEGFA) responding consistently to $10 \mathrm{uM}$ of isoproterenol.

\section{Comparison of $\mathrm{EC}_{50} \mathrm{~S}$ from single genes, gene-signatures, and CAMP}

A total of 21 beta agonists (Supplementary Table 2) covering a wide range of potencies ( $<10 \mathrm{pM}$ to ca. $5 \mathrm{uM})$, were chosen for this study. Other cAMP modulators were also included in this compound set: the histamine receptor $\mathrm{H} 3$ antagonist $\mathrm{N}$-alpha-methylhistamine and the adenylyl cyclase activator forskolin. As additional control, we added the beta-1 antagonist CGP-20712A, which, as expected, failed to increase cAMP levels. All compounds were measured in dose-response mode in the CAMP assay and for both gene signatures. An overview of dose-response curves of the genes is shown in Supplementary Fig. 2. The gene-expression data, derived gene-signature scores, and fitted $\mathrm{EC}_{50} \mathrm{~S}$ are presented in Supplementary Tables 3 and 4.

The relationship of $\mathrm{EC}_{50}$ values derived from genes and gene-signatures compared to cAMP-derived $E_{50}$ depends on the gene-signature methods used. Representative examples for method classes are shown in Fig. 2a. (all methods and genes are shown in Supplementary Fig. 3). The EC $\mathrm{F}_{50}$ S derived from direction-based methods cor_p_AC and cos_weight_AC are found almost entirely within a window of one log unit around the $\mathrm{CAMP}$-derived $\mathrm{EC}_{50} \mathrm{~S}$, which is very close considering the different incubation times and the different locations of the readouts in the adrenergic signaling pathway (gene expression vs CAMP). In contrast, the $\mathrm{EC}_{50}$ S derived from gene-signature methods containing magnitude information (scalar_projection_AC and vec_norm) and EC 50 S from the individual genes NR4A1 and THBS1 are almost all more than one log unit above the cAMP-derived EC 50 s. The ranking of cAMP potencies is not preserved as well (e.g. Spearman correlation for scalar_projection_AC to cAMP $=0.32$ ).

A performance overview of all genes and gene-signature methods is given in Fig. $2 b$. The similarity between gene or gene-signature derived $\mathrm{EC}_{50}$ s with $\mathrm{cAMP}$ derived $\mathrm{EC}_{50} \mathrm{~S}$ over all tested compounds is quantified by the Pearson correlation between logged $\mathrm{EC}_{50}$ s. Most methods within one method-class performed equally well. While direction\&magnitude and magnitude-based methods showed no significant difference to individual genes (TukeyHSD test with $p$-val < 0.05), direction-based methods performed significantly better than the other methods with Pearson correlations ranging between 0.6 and 0.9 . All other method classes showed mean Pearson correlations $<0.5$. The AC_similarity method performed significantly worse relative to others (only negative correlations). 

aCC-BY 4.0 International license.
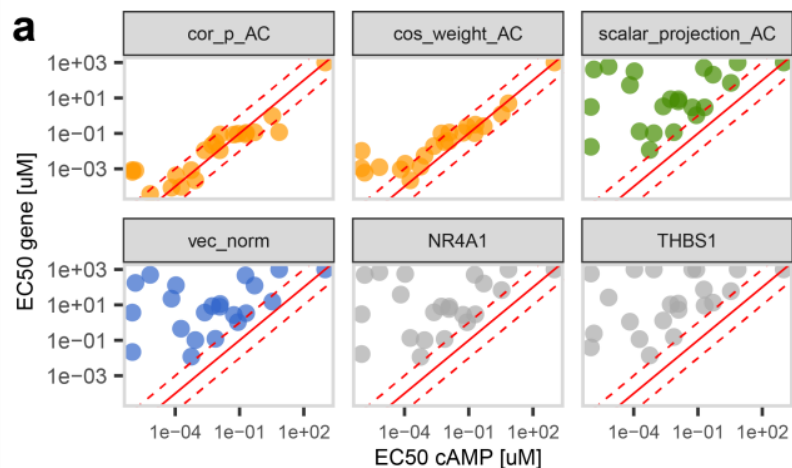

C
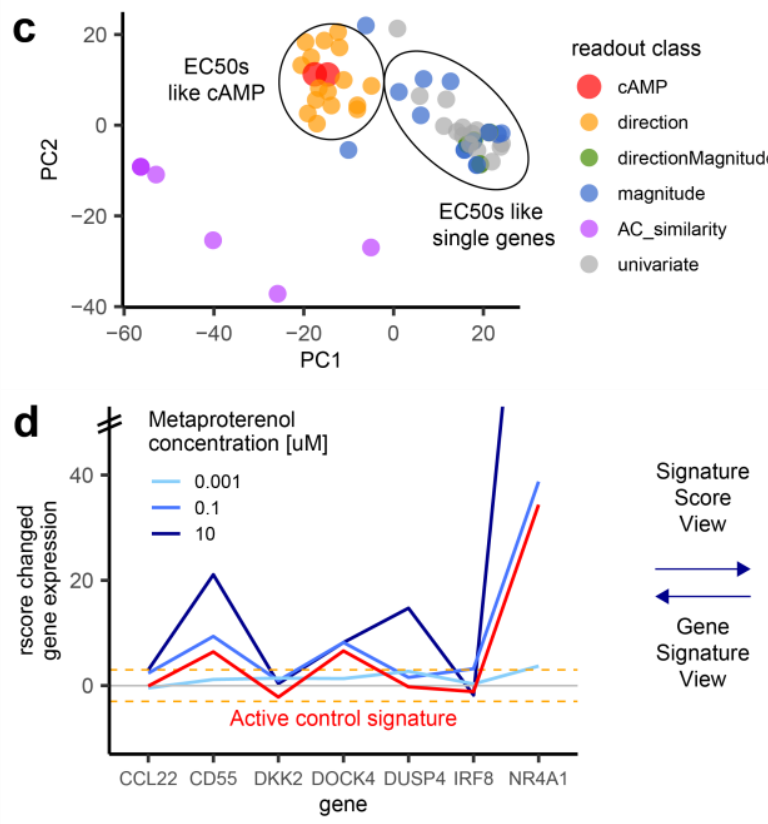

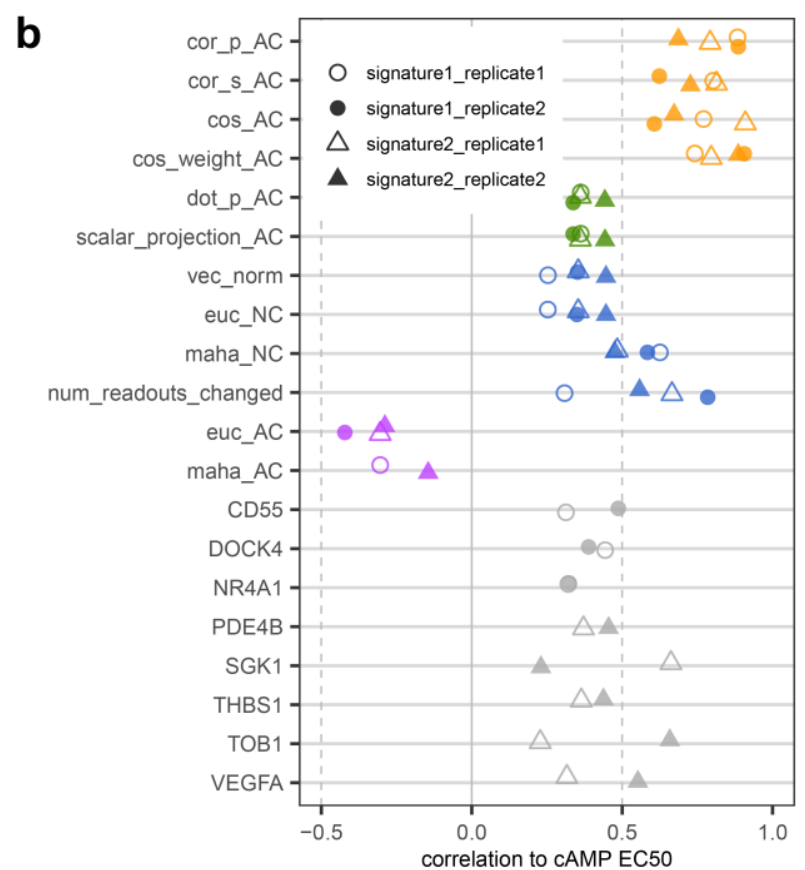

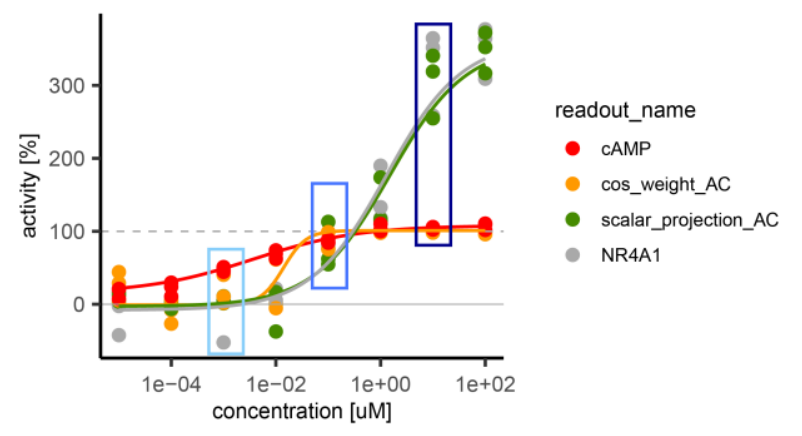

Figure 2: Comparison of $\mathrm{EC}_{50}$ s from gene-signatures, single-genes and cAMP for the beta agonists dataset. a) Example of gene and gene-signature $\mathrm{EC}_{50}$ s from representative methods compared to cAMP $\mathrm{EC}_{50}$ S. The dashed red lines indicates one log unit above and below the red line of equality. The shown gene and gene-signature $\mathrm{EC}_{50} \mathrm{~S}$ are from signature one, except THBS1 from signature two. The shown data is from replicate two. Axes are log10 transformed. b) Correlation of gene-signature and single-gene $\mathrm{EC}_{50}$ S with $\mathrm{CAMP} \mathrm{EC}_{50} \mathrm{~S}$. c) PCA of the cAMP, gene, and gene-signature summary methods logged $\mathrm{EC}_{50} \mathrm{~S}$ of all compounds in the dataset. Colors of a), b), and c) are according to the definition in c). d). Dose dependent change of the genes in the gene-signature (left panel, with $y$-axis values $>50$ not shown, orange dashed lines at three rscores indicating significant changes from the background), compared with the dose dependent change in gene-signature summary score methods and cAMP for metaproterenol (right panel, boxes colored according concentrations shown in left panel, dashed grey line at $100 \%$ activity).

The relationship between all gene-signature methods, single genes and CAMP EC 50 s is shown by a principle component analysis (PCA) projection of the dataset (Fig. 2c). Each data point represents the vector of logged $\mathrm{EC}_{50} \mathrm{~S}$ calculated by one method (for one replicate and one gene-signature) of all compounds in the dataset, Methods generating similar $\mathrm{EC}_{50} \mathrm{~S}$ are projected close to each other. The PCA 
projection confirms that direction methods cluster together with the $\mathrm{CAMP}^{\mathrm{E}} \mathrm{C}_{50}$, and all $\mathrm{EC}_{50}$ s containing magnitude information cluster together with single gene EC50s. As mentioned above, the AC_similarity methods are outliers relative to the two major clusters.

Fig. $2 \mathrm{~d}$ visualizes the expression levels of the individual genes over compound concentrations (left panel) and the resulting dose-response curves of derived multivariate $\mathrm{EC}_{50}$ methods (right panel). Increasing concentrations of metaproterenol result in increasing expression of the genes of the gene-signature. While the shape of the gene-signature remains similar to the active control signature (isoproterenol [10uM], red line), the magnitude of the metaproterenol signature exceeds the AC signature with increasing concentrations (left panel). The observed difference in gene expression magnitude between high concentrations of metaproterenol and the active control signature is only captured by metrics that make use of this information (Fig. 2d, right panel, green line). It is important to note that the difference between methods does not only lead to different maximal effect plateaus of the dose-response curve, but also to different $E_{50}$ values of the fitted curves.

The increase in gene expression beyond the active control also explains why AC_similarity methods cannot work in this scenario: the maximum similarity between compounds and $A \bar{C}$ signature is reached at identical magnitudes of both signatures. Both lower and larger magnitudes result in less similar signatures, resulting in bell shaped curves.

\section{EGFR inhibitors dataset from L1000}

For the L1000 EGFR ("Epidermal growth factor receptor") inhibitor dataset, we selected a set of eight EGFR inhibitors measured in six-point dose-response in MCF10A cells after $3 \mathrm{~h}$ and $24 \mathrm{~h}$ incubation time [11]. As reference univariate readout, the corresponding growth rate inhibition $\mathrm{GR}_{50}$ measured after three days was used [26]. As the LINC technology reported 12,717 genes, it was possible to test several genesignatures: (1) a published EGFR signature [28], and (2) a published cell proliferation gene-signature [3], further referred to by the gene name "Targeting protein for Xklp2" (TPX2). As a third biologically unbiased gene-set, all genes from L1000 were used for comparison. We also investigated the performance of single gene measurements, for which we chose the 20 genes from each of the three signatures with the strongest response to the active control (gefitinib at $3.33 \mathrm{uM}$ ).

Like with the beta agonist pathway data, gene-signature IC50S of the EGFR inhibitors corresponded well to the reference $\mathrm{GR}_{50}$ (Fig. 3a for representative readouts, all results in Supplementary Fig. 4-6). Results show a strong influence of the incubation time. At $24 \mathrm{~h}$ all shown gene-signature methods over all three gene-signatures resulted in $\mathrm{IC}_{50}$ vs $\mathrm{GR}_{50}$ correlations $>=0.88$, except scalar_projection_AC and vec_norm with the TPX2 gene-signature resulting in slightly lower correlations each of 0.68 . The individual single gene $\mathrm{IC}_{50} \mathrm{~S}$ at $24 \mathrm{~h}$ incubation showed more variance, with Pearson correlations ranging from -0.36 with the TPX2 signature to 0.9 with the EGFR signature. The individual genes from the EGFR signature resulted in the highest median correlation of 0.88 . Two very similar median correlations of 0.68 and 0.69 were found for the individual genes of the TPX2 signature and from all L1000 genes, confirming the lower biological relevance for the EGFR pathway of the latter signatures. Even though all three genesignatures contained individual genes that correlated very well with the GR50s (>0.9), all of them also contained genes with correlations to $\mathrm{GR}_{50} \mathrm{~S}<0.5$, few even around 0 . It is not clear how one could reliably distinguish more relevant from less relevant genes in the absence of another orthogonal reference-readout like the $\mathrm{GR}_{50}$ s.

At $3 \mathrm{~h}$ incubation time, differences between methods and gene-signatures are more pronounced, showing highest correlations for direction-based methods with the EGFR signature (both above 0.75). Again individual genes show a wide distribution of results ranging from -0.38 for TPX2 to ca. 0.85 for all three gene-sets. Like with the beta agonists, the values of gene-signature $\mathrm{IC}_{50} \mathrm{~S}$ are very close to the values 
from $\mathrm{GR}_{50}$ S and more than $50 \%$ of the gene-signature IC 50 values are within a one-log-unit window to the GR50S (Fig. 3b).

a
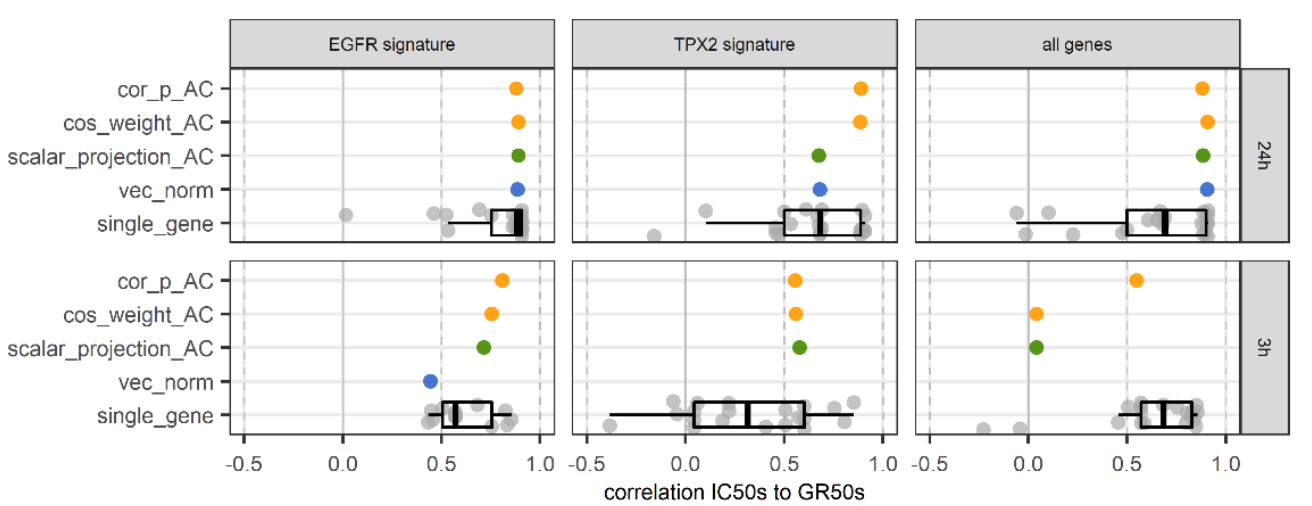

Method class

direction

- directionMagnitude

- magnitude

- univariate

b

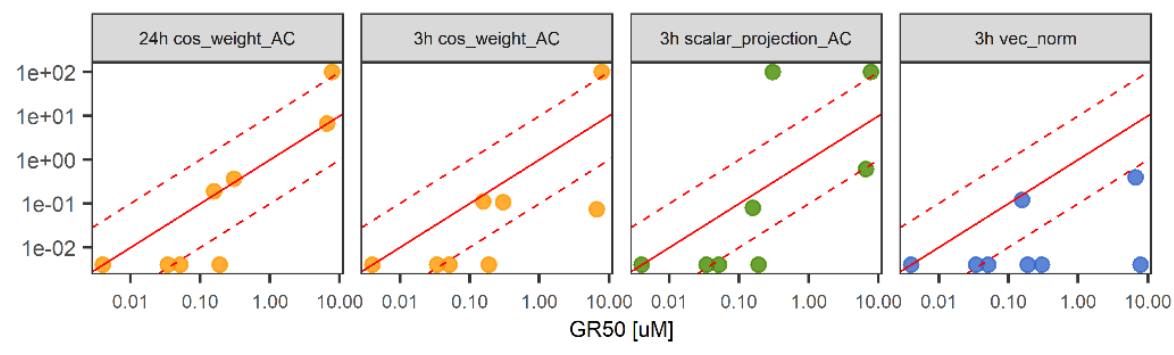

Method class

- direction

- directionMagnitude

- magnitude

Figure 3. Comparison of gene and gene-signature $\mathrm{IC}_{50}$ s to growth rate inhibition $\mathrm{GR}{ }_{50}$ of $\mathrm{EGFR}$ inhibitors. a) Pearson correlation of representative methods and 20 individual gene $I_{50}$ s to $G_{50}$ s. b) Comparison of representative EGFR gene-signature $\mathrm{IC}_{50}$ S in MCF10A vs. GR 50 s. The dashed red lines indicate one log unit above and below the red line of equality.

\section{Discussion}

The two main contributions of this work are: (1) the development and validation of an analytical framework for calculating compound potency based on multivariate readouts and (2) the provision of an open-source R-package to facilitate the application of our methods on new data by the scientific community.

The principal of this framework is to first summarize the information contained in multiple-genes into a single value and then pass it into a logistic function for potency estimation. The optimal metrics were selected based on their degree of concordance with compound potencies estimated with standard readouts $\left(\mathrm{CAMP} / \mathrm{GR}_{50}\right)$.

The fact that $\mathrm{IC}_{50} / \mathrm{EC}_{50}$ potency measurements are specific to a given biologic process (cAMP, gene expression, cell viability), and not a general property of the compound, is a potential challenge for comparing methods. However, choosing experimental models where gene expression is closely linked to pathway activation provides us confidence in our working model. The conservation of the compounds potency rank-order regardless of using gene expression or standard readouts supports our premise. Indeed, very close potency relationship (Pearson correlations up to 0.9 ) were observed for reference potency values (cAMP, GR ${ }_{50}$ ) upstream (cAMP) and downstream $\left(\mathrm{GR}_{50}\right)$ of the gene expression readout, and independent of very different compound incubation times of readouts. The assessments of optimal 
methods was not influenced by gene-signature composition. Indeed, all signatures used in this work were previously reported, or constructed independently of the screening datasets.

Of the five methodological classes of metrics: (1) direction-based, (2) distance based (magnitude) to the $\mathrm{NC}$, (3) distance based (magnitude) to the AC, (4) magnitude and direction-based and (5) single genes, results show that magnitude-based methods to the $A C$ clearly underperformed to other methods while direction-based methods performed consistently well in the two explored datasets. We did not find large differences in the performance of the methods within a single method class in these two datasets. Yet we recommend cos_weight_AC for direction-based methods due to its ability to down-weight signal with very small magnitude. To our surprise, adding information about the magnitude of the gene expression did not improve the results.

To this date, there is still very limited data available in the public domain that enables the comparison of multivariate $\mathrm{EC}_{50} / \mathrm{IC}_{50}$ with standard readouts, hence it is impossible to generalized current findings to future situations. Nonetheless, with the raise of novel sequencing methods that enable low to medium throughput compound screening based on hundreds to thousands of genes, the need for multivariate potency estimation will be strong.

Finally, our work enables the of use gene-signatures as screening readouts and biomarkers throughout all stages of research from early cell line experiments, to animal models and clinical studies. Using the same readout will in many cases contribute to increased biological relevancy at all stage of the drug discovery process. Similar multiplexed readouts like the data from cell painting or metabolomics [29, 30] might also benefit from our multiplexed potency methods.

The publication of the first dedicated dataset to investigate the quantification of the dose-response based on gene-signatures together with the first analysis of such data and the publication of an R-package providing the methods for such analyses will enable the further exploration and application of these methods by the scientific community. The algorithms and datasets used in the publications are available in the R-package mvAC50 from https://github.com/Novartis/mvAC50 .

\section{References}

1. Perou, C.M., et al., Molecular portraits of human breast tumours. Nature, 2000. 406(6797): p. 747-52.

2. Sotiriou, C., et al., Gene expression profiling in breast cancer: understanding the molecular basis of histologic grade to improve prognosis. J Natl Cancer Inst, 2006. 98(4): p. 262-72.

3. Farmer, P., et al., A stroma-related gene signature predicts resistance to neoadjuvant chemotherapy in breast cancer. Nat Med, 2009. 15(1): p. 68-74.

4. Lamb, J., et al., The Connectivity Map: using gene-expression signatures to connect small molecules, genes, and disease. Science, 2006. 313(5795): p. 1929-35.

5. Scherf, U., et al., A gene expression database for the molecular pharmacology of cancer. Nat Genet, 2000. 24(3): p. 236-44.

6. Li, H., J. Qu, and X.D. Fu, RASL-seq for massively parallel and quantitative analysis of gene expression. Curr Protoc Mol Biol, 2012. Chapter 4: p. Unit 413 1-9.

7. Ye, C., et al., DRUG-seq for miniaturized high-throughput transcriptome profiling in drug discovery. Nat Commun, 2018. 9(1): p. 4307.

8. Guibert, N., et al., Amplicon-based next-generation sequencing of plasma cell-free DNA for detection of driver and resistance mutations in advanced non-small cell lung cancer. Ann Oncol, 2018. 29(4): p. 1049-1055.

9. Xu, C., et al., Detecting very low allele fraction variants using targeted DNA sequencing and a novel molecular barcode-aware variant caller. BMC Genomics, 2017. 18(1): p. 5. 
10. Bush, E.C., et al., PLATE-Seq for genome-wide regulatory network analysis of high-throughput screens. Nat Commun, 2017. 8(1): p. 105.

11. Subramanian, A., et al., A Next Generation Connectivity Map: L1000 Platform and the First 1,000,000 Profiles. Cell, 2017. 171(6): p. 1437-1452 e17.

12. Chen, M.H., et al., Gene expression-based chemical genomics identifies potential therapeutic drugs in hepatocellular carcinoma. PLoS One, 2011. 6(11): p. e27186.

13. De Wolf, H., et al., High-Throughput Gene Expression Profiles to Define Drug Similarity and Predict Compound Activity. Assay Drug Dev Technol, 2018. 16(3): p. 162-176.

14. Hahn, C.K., et al., Proteomic and genetic approaches identify Syk as an AML target. Cancer Cell, 2009. 16(4): p. 281-94.

15. Hahn, C.K., et al., Expression-based screening identifies the combination of histone deacetylase inhibitors and retinoids for neuroblastoma differentiation. Proc Natl Acad Sci U S A, 2008.

105(28): p. 9751-6.

16. Peck, D., et al., A method for high-throughput gene expression signature analysis. Genome Biol, 2006. 7(7): p. R61.

17. Stegmaier, K., et al., Gene expression-based high-throughput screening(GE-HTS) and application to leukemia differentiation. Nat Genet, 2004. 36(3): p. 257-63.

18. House, J.S., et al., A Pipeline for High-Throughput Concentration Response Modeling of Gene Expression for Toxicogenomics. Front Genet, 2017. 8: p. 168.

19. Hu, J., et al., Analysis of dose-response effects on gene expression data with comparison of two microarray platforms. Bioinformatics, 2005. 21(17): p. 3524-9.

20. Ji, R.R., et al., Transcriptional profiling of the dose response: a more powerful approach for characterizing drug activities. PLoS Comput Biol, 2009. 5(9): p. e1000512.

21. Lin, D., et al., Classification of Trends in Dose-Response Microarray Experiments Using Information Theory Selection Methods. The Open Applied Informatics Journal, 2009(3): p. 34-43.

22. Lin, D., et al., Testing for trends in dose-response microarray experiments: a comparison of several testing procedures, multiplicity and resampling-based inference. Stat Appl Genet Mol Biol, 2007. 6: p. Article26.

23. Pramana, S., et al., IsoGene: An R Package for Analyzing Dose-response Studies in Microarray Experiments. The R Journal, 2010. 2(1): p. 5-12.

24. Duan, Q., et al., L1000CDS(2): LINCS L1000 characteristic direction signatures search engine. NPJ Syst Biol Appl, 2016. 2.

25. Gabriel, D., et al., High throughput screening technologies for direct cyclic AMP measurement. Assay Drug Dev Technol, 2003. 1(2): p. 291-303.

26. Hafner, M., et al., Growth rate inhibition metrics correct for confounders in measuring sensitivity to cancer drugs. Nat Methods, 2016. 13(6): p. 521-7.

27. Farmer, P. and J. Pugin, beta-adrenergic agonists exert their "anti-inflammatory" effects in monocytic cells through the IkappaB/NF-kappaB pathway. Am J Physiol Lung Cell Mol Physiol, 2000. 279(4): p. L675-82.

28. Creighton, C.J., et al., Activation of mitogen-activated protein kinase in estrogen receptor alphapositive breast cancer cells in vitro induces an in vivo molecular phenotype of estrogen receptor alpha-negative human breast tumors. Cancer Res, 2006. 66(7): p. 3903-11.

29. Abraham, Y., X. Zhang, and C.N. Parker, Multiparametric Analysis of Screening Data: Growing Beyond the Single Dimension to Infinity and Beyond. J Biomol Screen, 2014. 19(5): p. 628-39.

30. Loo, L.H., L.F. Wu, and S.J. Altschuler, Image-based multivariate profiling of drug responses from single cells. Nat Methods, 2007. 4(5): p. 445-53.

31. Liberzon, A., et al., Molecular signatures database (MSigDB) 3.0. Bioinformatics, 2011. 27(12): $\mathrm{p}$. 1739-40.

32. Subramanian, A., et al., Gene set enrichment analysis: a knowledge-based approach for interpreting genome-wide expression profiles. Proc Natl Acad Sci U S A, 2005. 102(43): p. 15545-50.

33. Gubler, H., et al., Helios: History and Anatomy of a Successful In-House Enterprise HighThroughput Screening and Profiling Data Analysis System. SLAS Discov, 2018. 23(5): p. 474488. 


\section{Abbreviations}

CMap: Connectivity Map

$\mathrm{EC}_{50}=$ Compound concentration of half-maximal activating effect.

$\mathrm{IC}_{50}=$ Compound concentration of half-maximal inhibitory effect.

$\mathrm{AC}_{50}=$ Compound concentration of half-maximal effect, independent of curve direction. General term including both $\mathrm{EC}_{50}$ and $\mathrm{IC}_{50}$.

$\mathrm{GR}_{50}=$ Compound concentration of $50 \%$ reduction of the $\mathrm{GR}$ values, where the GR value is the ratio between growth rates under treated and untreated conditions normalized to a single cell division.

$\mathrm{AC}=$ active control.

$\mathrm{NC}=$ neutral control.

\section{Methods}

THP1 cells

Human promonocytic THP-1 cells (TIB-202, ATCC) were cultured at $37^{\circ} \mathrm{C} / \mathrm{CO}_{2}$ in medium (Hepes (72400-054, Life Technologies), with 10\% FBS (2-01F16-I, Amimed/Bioconcept), 1\% Pen/Strep (15140122, Life Technologies), $1 \mathrm{mM}$ Sodium Pyruvate (11360-039, Life Technologies), 2mM L-Glutamine (25030-024, Life Technologies), 0.0mM Mercaptoethanol (31350-010, Life Technologies)). Before compound treatment and for all experiments, the THP1 cells were differentiated with 100nM Vitamin $\mathrm{D}_{3}$ (Biotrend Chemicals AG, Switzerland, Cat. No. BG0684) for 3 days at $37^{\circ} \mathrm{C} / \mathrm{CO}_{2}$.

\section{cAMP HTRF assay}

The assay was run using the Cisbio cAMP dynamic 2 Kit (62AM4PEB), in white 384well-plates BioCoat \#354661, with 20,000 cells/well in 10 $\mu \mathrm{L} /$ well HBSS/HEPES/IBMX. Isoproterenol [10uM] was used as active control. Cells were incubated with compounds for $20 \mathrm{~min}$. at $37^{\circ} \mathrm{C}$ in $\mathrm{HBSS} / \mathrm{HEPES}$, in the presence of the Phosphodiesterase (PDE) inhibitor IBMX. Then, cells were lysed and the amount of generated cAMP was quantified by HTRF (Homogeneous Time Resolved Fluorescence).

\section{Beta agonists gene-signature.}

RNASeq experiments were done comparing untreated cells with a treatment with isoproterenol, adrenaline or noradrenaline for $4 \mathrm{~h}$ in THP1 cells.

qPCR was run in THP1 cells for 4h incubation time with isoproterenol and formoterol at 1, 10 and $100 \mathrm{nM}$. Total RNAs were isolated with MagMAX ${ }^{\mathrm{TM}}$-96 Total RNA Isolation Kit (Ambion ref\#AM1830), and cDNA was made using a cDNA Synthesis Kit (Applied Biosystems ${ }^{\text {TM }}$ Ref\#4368813 ) RT-PCRs were performed in 384-well plates on an AB7900HT cycler (Applied Biosystems) using specific TaqMan probes (Applied Biosystems). Housekeeper normalization was done relative to the one of the three genes GAPDH, PPIB or TBP, which had the most similar expression level to the gene of interest, according to our DMSO qPCR data. All measurements were done in quadruplicates. 


\section{QuantiGene Plex assay}

Gene expression changes were measured using a customized QuantiGene Plex assay (Thermo Fisher Scientific).

Two different eight-gene-signatures were designed (obtained from Thermo Fisher Scientific), as the internal QuantiGene process was set up to handle custom-designed signatures of eight genes. Each of the eight-gene-signatures consisted of seven target genes responding to CAMP and one housekeeper gene (TBP).

Measurements were done in THP1 cells. Compounds were measured in six replicates on the same day on different plates, and the procedure was repeated on another day using three replicates on different plates (referred to as biological replicates in the manuscript).

For the assay, 100,000 cells were seeded in a volume of $20 \mathrm{uL}$ in each well of a 384 well plate (Greiner PP V bottom 781280). Compounds were added in serial dilutions of 1:10 (200nL volume added per well) with maximal compound concentrations of $100 \mathrm{uM}$. After $4 \mathrm{~h}$ incubation, cells were lysed with QuantiGene lysis mixture (10uL), and after 2 min, stored at $-80^{\circ} \mathrm{C}$.

Targeted mRNA transcripts were captured to their respective beads by combining lysis mixture (5uL), blocking reagent $(2 \mathrm{uL})$, probe mix $(1.125 \mathrm{uL})$, water $(11.25 \mathrm{uL})$, and magnetic beads $(0.3 \mathrm{uL} ; 500$ beads/region/uL) and incubated overnight.

Signal amplification via branched DNA is added by sequential hybridization of 2.0 Pre Amplifier biotinylated label probe, and binding with Steptavidin-conjugated Phycoerythrin (SAPE). For this purpose, each 15uL/well pre-amplifier, amplifier and label probe \& SAPE were added after washing followed by $1 \mathrm{~h}$ incubation at $50^{\circ} \mathrm{C}$ and multitron shaking $300 \mathrm{rpm} 1 \mathrm{~h}$.

The amount of RNA in 90uL of probe was quantified using a Luminex Flexmap 3D instrument (Luminex). The identity of the mRNA is encoded by the hybridized Luminex beads, and the level of SAPE fluorescence is proportional to the amount of mRNA transcripts captured by the respective beads.

\section{QuantiGene Plex data processing}

The raw readout of the assay was processed as follows:

1. Fold change $=50{ }^{*} \log _{2}($ mRNA count / median mRNA count for NC well $)$

2. Rscore $=($ Fold change for well - median Fold change for NC wells ) / MAD (mRNA count for NC wells)

3. HKnorm = Rscore for well - HK_Rscore for well; with HK = housekeeper gene.

\section{L1000 / GR50 dataset}

EGFR inhibitors in MCF10A cells were selected as model system, because (1) they showed a strong $\mathrm{GR}_{50}$ dynamic range (Dose-response curves visualization http://www.grcalculator.org/grbrowser/.), and

(2) were measured in six concentrations in L1000 (10uM, 3.33uM, 1.11uM, 0.37uM, 0.12uM, 0.04uM).

The L1000 data was obtained in two files

(GSE70138_Broad_LINCS_Level4_ZSVCINF_mlr12k_n78980x22268_2015-06-30.gct.gz and

GSE70138_Broad_LINCS_Level4_ZSVCINF_mlr12k_n115209x22268_2015-12-31.gct.gz) from NCBI

GEO (https://www.ncbi.nlm.nih.gov/geo/query/acc.cgi?acc=GSE70138).

This version of the data contains the changed gene-expression normalized as z-scores relative to the DMSO controls on each plate, a similar normalization procedure to the one performed for the beta- 
agonists expression data. When multiple probes were measured for the same gene_symbol, the probe with the highest variance was kept, for each timepoint. The gefitinib treatment at $3.33 \mathrm{uM}$ was defined as the active control of the experiment. Compounds, smiles, and inchi_key were downloaded from the LINCS webpage (http://lincs.hms.harvard.edu/db/datasets/20000/).

From the 12,727 genes in the L1000 dataset, two different subsets were selected based on published gene-signatures. An EGFR (entrez gene_id 1956) signature [28] (“EGFR_UP.V1_UP” with 193 genes, "EGFR_UP.V1_DN" with 196 genes) was downloaded from msigdb [31, 32], of which a total of 381 genes could be mapped to the L1000 data. This gene-signature was derived from profiling of MCF-7 cell lines stably overexpressing ligand-activatable EGFR. A TPX2 (entrez gene_id 22974) signature (50 genes, of which 39 could be mapped to L1000) was taken from Farmer et al [3], representing a more general signature for cell proliferation.

The $\mathrm{GR}_{50}$ cell viability potency values after three days compound incubation time were also obtained from the LINCS consortium (http://lincs.hms.harvard.edu/db/datasets/20252/results). To make the data more comparable to the fitted $I_{50}$ 's from the gene-signatures, compounds with flat $\mathrm{GR}_{50}$ dose-response curves were set to either one log unit above or below the highest or lowest tested concentration, depending whether their fitted GRInf value was larger or smaller than 0.5 .

As the files from L1000 and the GR50s contained slightly different compound and cell line names, the names were set all to lowercase and whitespaces and "-" were removed. Eight known EGFR inhibitors afatinib, neratinib, pelitinib, gefitinib, erlotinib, canertinib, lapatinib, and HG-5-88-01 overlapped between the two datasets. The two EGFR/ERBB2 dual inhibitors neratinib and afatinib were considered as EGFR inhibitors for this study (even though they are annotated as ERBB2 inhibitors in the LINCS nominal target annotation).

\section{Dose-response (DRC) fitting}

Four-point parametric logistic fits were calculated with an R function included in the mvAC50 R-package [https://github.com/Novartis/mvAC50]. The fitting algorithm was adopted from our in-house HTS analysis software Helios [33]. The fits were constrained to A0 and Ainf (minimal and maximal fitted activities) between $-50 \%$ and $500 \%$ of the active control effect, respectively, and a hill slope between 0.1 and 10 . The $\mathrm{IC}_{50} \mathrm{~S}$ or $\mathrm{EC}_{50} \mathrm{~S}$ were constrained to one log unit above and below the experimentally measured range of concentrations, (for the beta agonists ranging from $0.00001 \mathrm{uM}$ to $100 \mathrm{uM}$, and for the $\mathrm{L} 1000$ data ranging from $0.04 \mathrm{uM}$ to $10 \mathrm{uM}$ )

In the case of constant fits, $\mathrm{IC}_{50}$ or $\mathrm{EC}_{50}$ values one-log unit above or below the range of tested concentrations were assigned to the compounds to be able to use those data points as well in the correlation of calculated potencies to the reference potencies. Depending on whether the Amax of the constant fit was below or above $50 \%$, a potency of either one log unit below or above the tested concentration range was assigned. Fitted $A_{50}$ s with Ainf values $<50 \%$ were set to one log unit above the highest tested concentration as well, assuming that the observed effect is not caused by the same mode of action as in the active control.

In parallel to the four-point parametric fit and constant fits, a nonparametric fit was also calculated and compared to the other fits, to allow for more unusual curve shapes, e.g. bell shaped curves. For these fits the reported potency is the concentration at which the fit crosses the line of $50 \%$ activity. The decision for the reported fit and potency was done as follows: If the non-parametric fit resulted in $\mathrm{r} 2<0.5$, the data was considered as not suitable for curve fitting and assigned as constant fit. If the curve had a bell-shape, the nonparametric potency was reported. If parametric fits had $\mathrm{r} 2<0.5$ or the absolute (amin-amax) $<30$, a constant fit was reported as well, where amin and amax correspond to A0 and Ainf within the measured concentration range. For the remaining curves (the majority) parametric potencies were reported. 
bioRxiv preprint doi: https://doi org/10.1101/799106; this version posted October 9 , 2019. The copyright holder for this preprint (which was not certified by peer review) is the author/funder, who has granted bioRxiv a license to display the preprint in perpetuity. It is made available under aCC-BY 4.0 International license.

CAMP EC50S were fitted with the same algorithm and settings, to ensure a higher consistency in the data. The fitted cAMP EC 50 s were in agreement with the fits generated by the biologists who ran the assays. For the $\mathrm{GR}_{50}$ dataset this approach was not feasible, as no raw data was available, and the $\mathrm{GR}_{50}$ algorithm was claimed to be superior to four-point parametric fits of the same data [26].

\section{Acknowledgment}

We would like to acknowledge Stan Lazic, Xian Zhang, and Jeremy Jenkins for helpful discussions about the concept of multivariate $\mathrm{AC}_{50} \mathrm{~s}$, Wendy Broom, Elaine Donohue and Jacques Hamon for help with the QuantiGene assay, Magalie Mathies for help with setting up the THP-1 assays, Pierre Rigo, Thomas Hoerter, Cornelia Mouzo and Valerie Heidinger for production of THP-1 cells, loannis Moutsatsos for help with the QuantigGene analysis pipeline, and Pascale Anderle for referring Andrea Amati as NIBR intern for this project. 
bioRxiv preprint doi: https://doi org/10.1101/799106; this version posted October 9 2019. The copyright holder for this preprint (which was not certified by peer review) is the author/funder, who has granted bioRxiv a license to display the preprint in perpetuity. It is made available under aCC-BY 4.0 International license.

\section{Supplementary Information}

Supplementary Table 1: Genes selected for quantification of beta agonist potencies.

\begin{tabular}{|l|l|l|l|l|}
\hline Gene symbol & Gene id & Name & Set & Comment \\
\hline CCL22 & 6367 & C-C motif chemokine ligand 22 & 1 & \\
\hline CD55 & 1604 & CD55 molecule (Cromer blood group) & 1 & \\
\hline DKK2 & 27123 & dickkopf WNT signaling pathway inhibitor 2 & 1 & \\
\hline DOCK4 & 9732 & dedicator of cytokinesis 4 & 1 & \\
\hline DUSP4 & 1846 & dual specificity phosphatase 4 & 1 & \\
\hline IRF8 & 3394 & interferon regulatory factor 8 & 1 & \\
\hline NR4A1 & 3164 & nuclear receptor subfamily 4 group A member 1 & 1 & \\
\hline TBP & 6908 & TATA-box binding protein & 1 & Housekeeper \\
\hline NR4A3 & 8013 & nuclear receptor subfamily 4 group A member 3 & 2 & \\
\hline PDE4B & 5142 & phosphodiesterase 4B & 2 & \\
\hline PPARGC1B & 133522 & PPARG coactivator 1 beta & 2 & \\
\hline SGK1 & 6446 & serum/glucocorticoid regulated kinase 1 & 2 & \\
\hline THBS1 & 6908 & TATA-box binding protein & 2 & \\
\hline TOB1 & 7057 & thrombospondin 1 & 2 & \\
\hline VEGFA & 10140 & transducer of ERBB2, 1 & 2 & \\
\hline TBP & 7422 & vascular endothelial growth factor A & 2 & Housekeeper \\
\hline
\end{tabular}


bioRxiv preprint doi: https://doi org/10 1101/799106; this version posted October 9 2019. The copyright holder for this preprint (which was not certified by peer review) is the author/funder, who has granted bioRxiv a license to display the preprint in perpetuity. It is made available under aCC-BY 4.0 International license.

\section{Supplementary Table 2: Overview over compounds used in THP1 experiments, comparing cAMP and QuantiGene readouts.}

\begin{tabular}{|c|c|c|c|c|c|c|c|}
\hline Compound & MOA & Inchi_key & Smiles & $\mathrm{EC}_{50}$ repl1 & $\begin{array}{l}\text { Amax } \\
\text { repl1 }\end{array}$ & $\begin{array}{l}\mathrm{EC}_{50} \\
\text { repl2 }\end{array}$ & $\begin{array}{l}\text { Amax } \\
\text { repl2 }\end{array}$ \\
\hline $\begin{array}{l}(+/-)- \\
\text { isoproterenol }\end{array}$ & beta agonist & $\begin{array}{l}\text { JWZZKOKVBUJMES- } \\
\text { UHFFFAOYSA-N }\end{array}$ & $\mathrm{CC}(\mathrm{C}) \mathrm{NCC}(\mathrm{O}) \mathrm{c} 1 \mathrm{ccc}(\mathrm{O}) \mathrm{c}(\mathrm{O}) \mathrm{c} 1$ & 0.00008 & 109 & $<0.00001$ & 110 \\
\hline terbutaline & beta agonist & $\begin{array}{l}\text { XWTYSIMOBUGWOL- } \\
\text { UHFFFAOYSA-N }\end{array}$ & $\mathrm{CC}(\mathrm{C})(\mathrm{C}) \mathrm{NCC}(\mathrm{O}) \mathrm{c} 1 \mathrm{cc}(\mathrm{O}) \mathrm{cc}(\mathrm{O}) \mathrm{c} 1$ & 0.713 & 101 & 0.202 & 98 \\
\hline fenoterol & beta agonist & $\begin{array}{l}\text { LSLYOANBFKQKPT- } \\
\text { UHFFFAOYSA-N }\end{array}$ & $\mathrm{CC}(\mathrm{Cc} 1 \mathrm{ccc}(\mathrm{O}) \mathrm{cc} 1) \mathrm{NCC}(\mathrm{O}) \mathrm{c} 2 \mathrm{cc}(\mathrm{O}) \mathrm{cc}(\mathrm{O}) \mathrm{c} 2$ & 0.0036 & 106 & 0.0013 & 111 \\
\hline adrenaline & beta agonist & $\begin{array}{l}\text { UCTWMZQNUQWSLP- } \\
\text { VIFPVBQESA-N }\end{array}$ & $\mathrm{CNC}[\mathrm{C} @ \mathrm{H}](\mathrm{O}) \mathrm{c} 1 \mathrm{ccc}(\mathrm{O}) \mathrm{c}(\mathrm{O}) \mathrm{c} 1$ & 0.139 & 106 & 0.0171 & 115 \\
\hline metaproterenol & beta agonist & $\begin{array}{l}\text { LMOINURANNBYCM- } \\
\text { UHFFFAOYSA-N }\end{array}$ & $\mathrm{CC}(\mathrm{C}) \mathrm{NCC}(\mathrm{O}) \mathrm{c} 1 \mathrm{cc}(\mathrm{O}) \mathrm{cc}(\mathrm{O}) \mathrm{c1}$ & 0.0036 & 108 & 0.0141 & 111 \\
\hline isoetharine & beta agonist & $\begin{array}{l}\text { HUYWAWARQUIQLE- } \\
\text { UHFFFAOYSA-N }\end{array}$ & $\mathrm{CCC}(\mathrm{NC}(\mathrm{C}) \mathrm{C}) \mathrm{C}(\mathrm{O}) \mathrm{c} 1 \mathrm{ccc}(\mathrm{O}) \mathrm{c}(\mathrm{O}) \mathrm{c} 1$ & 0.0012 & 93 & 0.0115 & 108 \\
\hline BRL 37344 & beta agonist & $\begin{array}{l}\text { ZGGNJJJYUVRADP- } \\
\text { UHFFFAOYSA-N }\end{array}$ & $\begin{array}{l}\mathrm{CC}(\mathrm{Cc} 1 \mathrm{ccc}(\mathrm{cc} 1) \mathrm{OCC}(\mathrm{O})=\mathrm{O}) \mathrm{NCC}(\mathrm{O}) \mathrm{c} 2 \mathrm{cccc}(\mathrm{Cl}) \mathrm{c} \\
2\end{array}$ & 0.0282 & 84 & 0.0984 & 91 \\
\hline ritodrine & beta agonist & $\begin{array}{l}\text { IOVGROKTTNBUGK- } \\
\text { SJCJKPOMSA-N }\end{array}$ & $\begin{array}{l}\mathrm{C}[\mathrm{C} @ \mathrm{H}](\mathrm{NCCc} 1 \mathrm{ccc}(\mathrm{O}) \mathrm{cc} 1)[\mathrm{C} @ \mathrm{H}](\mathrm{O}) \mathrm{c} 2 \mathrm{ccc}(\mathrm{O}) \mathrm{cc} \\
2\end{array}$ & 0.846 & 91 & 0.51 & 83 \\
\hline norepinephrine & beta agonist & $\begin{array}{l}\text { SFLSHLFXELFNJZ- } \\
\text { QMMMGPOBSA-N }\end{array}$ & $\mathrm{NC}[\mathrm{C} @ \mathrm{H}](\mathrm{O}) \mathrm{c} 1 \mathrm{ccc}(\mathrm{O}) \mathrm{c}(\mathrm{O}) \mathrm{c} 1$ & 0.0002792 & 109 & $\begin{array}{l}0.000582 \\
9\end{array}$ & 115 \\
\hline procaterol & beta agonist & $\begin{array}{l}\text { FKNXQNWAXFXVNW- } \\
\text { BLLLJJGKSA-N }\end{array}$ & $\begin{array}{l}\mathrm{CC}[\mathrm{C} @ \mathrm{H}](\mathrm{NC}(\mathrm{C}) \mathrm{C})[\mathrm{C} @ \mathrm{H}](\mathrm{O}) \mathrm{c} 1 \mathrm{ccc}(\mathrm{O}) \mathrm{c} 2 \mathrm{NC}(=\mathrm{O}) \\
\mathrm{C}=\mathrm{Cc} 12\end{array}$ & 0.008542 & 93 & 0.00013 & 102 \\
\hline dobutamine & beta agonist & $\begin{array}{l}\text { JRWZLRBJNMZMFE- } \\
\text { UHFFFAOYSA-N }\end{array}$ & $\mathrm{CC}(\mathrm{CCc} 1 \mathrm{ccc}(\mathrm{O}) \mathrm{cc} 1) \mathrm{NCC} 2 \mathrm{ccc}(\mathrm{O}) \mathrm{c}(\mathrm{O}) \mathrm{c2}$ & 0.0008564 & 106 & 0.00242 & 106 \\
\hline abediterol & beta agonist & $\begin{array}{l}\text { SFYAXIFVXBKRPK- } \\
\text { QFIPXVFZSA-N }\end{array}$ & $\begin{array}{l}\text { O[C@@ } @ \mathrm{H}](\mathrm{CNCCCCCCOCC}(\mathrm{F})(\mathrm{F}) \mathrm{c} 1 \mathrm{ccccc} 1) \mathrm{c} 2 \mathrm{c} \\
\operatorname{cc}(\mathrm{O}) \mathrm{c} 3 \mathrm{NC}(=\mathrm{O}) \mathrm{C}=\mathrm{Cc} 23\end{array}$ & $<0.00001$ & 101 & $<0.00001$ & 105 \\
\hline olodaterol & beta agonist & $\begin{array}{l}\text { COUYJEVMBVSIHV- } \\
\text { SFHVURJKSA-N }\end{array}$ & $\begin{array}{l}\mathrm{COc3ccc}(\mathrm{CC}(\mathrm{C})(\mathrm{C}) \mathrm{NC}[\mathrm{C} @ \mathrm{H}](\mathrm{O}) \mathrm{c} 2 \mathrm{cc}(\mathrm{O}) \operatorname{cc} 1 \mathrm{NC}(= \\
\mathrm{O}) \mathrm{COc} 12) \operatorname{cc} 3\end{array}$ & 0.00001869 & 97 & $<0.00001$ & 102 \\
\hline batefenterol & beta agonist & $\begin{array}{l}\text { URWYQGVSPQJGGB- } \\
\text { DHUJRADRSA-N }\end{array}$ & $\begin{array}{l}\mathrm{COC} 4 \mathrm{cc}(\mathrm{NC} C=\mathrm{O}) \mathrm{CCN} 1 \mathrm{CCC}(\mathrm{CC} 1) \mathrm{OC}(=\mathrm{O}) \mathrm{Nc} 2 \mathrm{ccc} \\
\mathrm{cc} 2 \mathrm{c} 3 \mathrm{ccccc} 3) \mathrm{c}(\mathrm{Cl}) \mathrm{cc} 4 \mathrm{CNC}[\mathrm{C} @ \mathrm{H}](\mathrm{O}) \mathrm{c} 5 \operatorname{ccc}(\mathrm{O}) \mathrm{c6} 6 \\
\mathrm{NC}(=\mathrm{O}) \mathrm{C}=\mathrm{Cc} 56\end{array}$ & 0.0021 & 101 & $1.89 \mathrm{E}-04$ & 101 \\
\hline vilanterol & beta agonist & $\begin{array}{l}\text { DAFYYTQWSAWIGS- } \\
\text { DEOSSOPVSA-N }\end{array}$ & $\begin{array}{l}\text { OCc1cc(ccc1O)[C@@H](O)CNCCCCCCOCCO } \\
\text { Cc2c(Cl)cccc2Cl }\end{array}$ & 0.00001721 & 96 & $<0.00001$ & 98 \\
\hline tulobuterol & beta agonist & $\begin{array}{l}\text { YREYLAVBNPACJM- } \\
\text { UHFFFAOYSA-N }\end{array}$ & $\mathrm{CC}(\mathrm{C})(\mathrm{C}) \mathrm{NCC}(\mathrm{O}) \mathrm{c} 1 \mathrm{ccccc} 1 \mathrm{Cl}$ & 0.016 & 68 & 0.0366 & 50 \\
\hline salbutamol & beta agonist & $\begin{array}{l}\text { NDAUXUAQIAJITI- } \\
\text { UHFFFAOYSA-N }\end{array}$ & $\mathrm{CC}(\mathrm{C})(\mathrm{C}) \mathrm{NCC}(\mathrm{O}) \mathrm{c} 1 \mathrm{ccc}(\mathrm{O}) \mathrm{c}(\mathrm{CO}) \mathrm{c} 1$ & 0.02 & 89 & 0.004285 & 88 \\
\hline zinterol & beta agonist & $\begin{array}{l}\text { XJBCFFLVLOPYBV- } \\
\text { UHFFFAOYSA-N }\end{array}$ & $\begin{array}{l}\mathrm{CC}(\mathrm{C})(\mathrm{Cc} 1 \mathrm{ccccc} 1) \mathrm{NCC}(\mathrm{O}) \mathrm{c} 2 \mathrm{ccc}(\mathrm{O}) \mathrm{c}(\mathrm{c} 2) \mathrm{NS}(\mathrm{C})(= \\
\mathrm{O})=\mathrm{O}\end{array}$ & $<0.00001$ & 99 & $\begin{array}{l}0.000043 \\
44\end{array}$ & 95 \\
\hline tretoquinol & beta agonist & $\begin{array}{l}\text { RGVPOXRFEPSFGH- } \\
\text { UHFFFAOYSA-N }\end{array}$ & $\mathrm{COc3cc}(\mathrm{CC} 1 \mathrm{NCC} 2 \mathrm{cc}(\mathrm{O}) \mathrm{c}(\mathrm{O}) \mathrm{cc} 12) \mathrm{cc}(\mathrm{OC}) \mathrm{c} 3 \mathrm{OC}$ & 0.00005932 & 101 & $<0.00001$ & 105 \\
\hline dopexamine & beta agonist & $\begin{array}{l}\text { RYBJORHCUPVNMB- } \\
\text { UHFFFAOYSA-N }\end{array}$ & Oc2ccc(CCNCCCCCCNCCc1 $1 \operatorname{ccccc} 1) \operatorname{cc} 2 \mathrm{O}$ & 4.1 & 56 & 5.837 & 62 \\
\hline formoterol & beta agonist & $\begin{array}{l}\text { BPZSYCZIITTYBL- } \\
\text { YJYMSZOUSA-N }\end{array}$ & $\begin{array}{l}\mathrm{COc2ccc}(\mathrm{C}[\mathrm{C} @ @ \mathrm{H}](\mathrm{C}) \mathrm{NC}[\mathrm{C} @ \mathrm{H}](\mathrm{O}) \mathrm{c} 1 \mathrm{ccc}(\mathrm{O}) \mathrm{c}(\mathrm{c} \\
\text { 1)NC=O)cc2 }\end{array}$ & 0.00001267 & 106 & $\begin{array}{l}0.000023 \\
1\end{array}$ & 109 \\
\hline forskolin & AC activator & $\begin{array}{l}\text { OHCQJHSOBUTRHG- } \\
\text { KENMSXPPSA-N }\end{array}$ & $\begin{array}{l}\mathrm{CC}(=\mathrm{O}) \mathrm{OC} 2 \mathrm{C}(\mathrm{O})[\mathrm{C} @ \mathrm{H}] 1 \mathrm{C}(\mathrm{C})(\mathrm{C}) \mathrm{CC}[\mathrm{C} @ \mathrm{H}](\mathrm{O})[\mathrm{C} \\
@] 1(\mathrm{C})[\mathrm{C} @ @] 3(\mathrm{O}) \mathrm{C}(=\mathrm{O}) \mathrm{C}[\mathrm{C} @](\mathrm{C})(\mathrm{C}=\mathrm{C}) \mathrm{O}[\mathrm{C} @] \\
23 \mathrm{C}\end{array}$ & 6.283 & 90 & 3.757 & 104 \\
\hline $\begin{array}{l}\mathrm{N} \text {-alpha- } \\
\text { methylhistamine }\end{array}$ & $\begin{array}{l}\text { histamine } \mathrm{H} 3 \\
\text { antagonist }\end{array}$ & $\begin{array}{l}\text { PHSPJQZRQAJPPF- } \\
\text { UHFFFAOYSA-N }\end{array}$ & $\mathrm{CNCCC} 1=\mathrm{CNC}=\mathrm{N} 1$ & 0.161 & 98 & 0.199 & 102 \\
\hline CGP-20712A & $\begin{array}{l}\text { beta-1 } \\
\text { antagonist }\end{array}$ & $\begin{array}{l}\text { GKJZEKSHCJELPL- } \\
\text { UHFFFAOYSA-N }\end{array}$ & $\begin{array}{l}\mathrm{CN1C}=\mathrm{C}(\mathrm{N}=\mathrm{C} 1 \mathrm{c} 2 \mathrm{ccc}(\mathrm{cc} 2) \mathrm{OCC}(\mathrm{O}) \mathrm{CNCCOc3ccc} \\
(\mathrm{O}) \mathrm{c}(\mathrm{c} 3) \mathrm{C}(\mathrm{N})=\mathrm{O}) \mathrm{C}(\mathrm{F})(\mathrm{F}) \mathrm{F}\end{array}$ & $>100$ & -17 & $>100$ & -19 \\
\hline
\end{tabular}


bioRxiv preprint doi: https://doi.org/10.1101/799106; this version posted October 9 2019. The copyright holder for this preprint (which was not certified by peer review) is the author/funder, who has granted bioRxiv a license to display the preprint in perpetuity. It is made available under aCC-BY 4.0 International license.

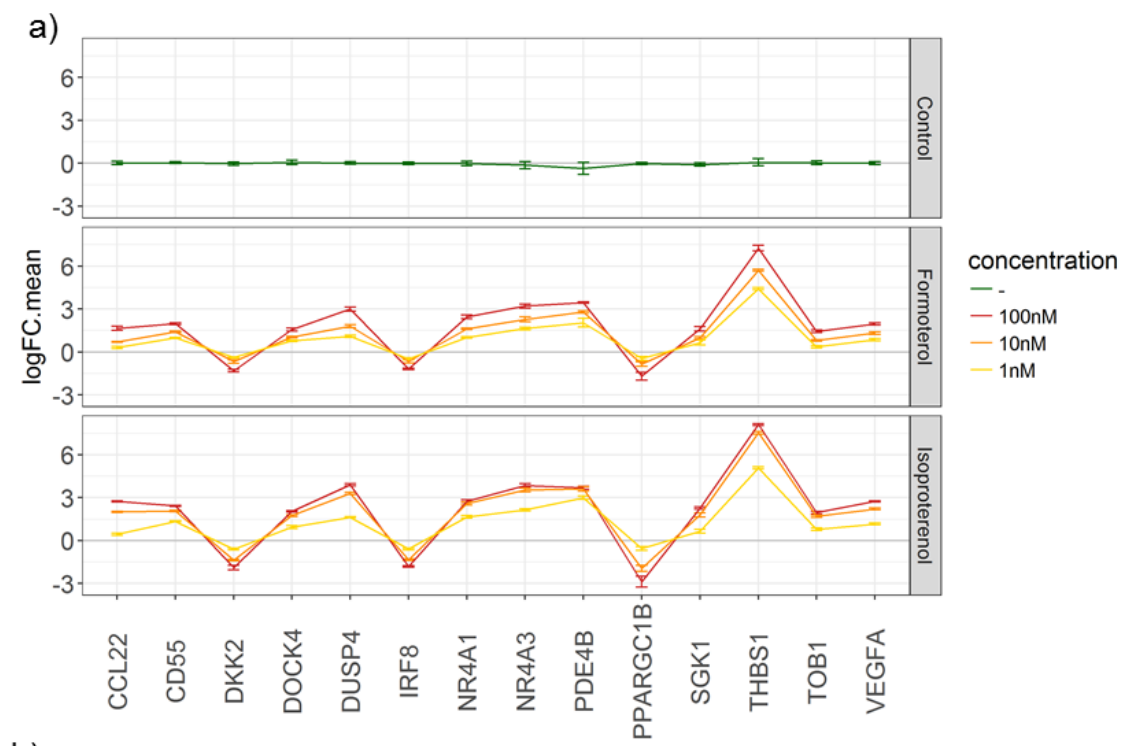

b)

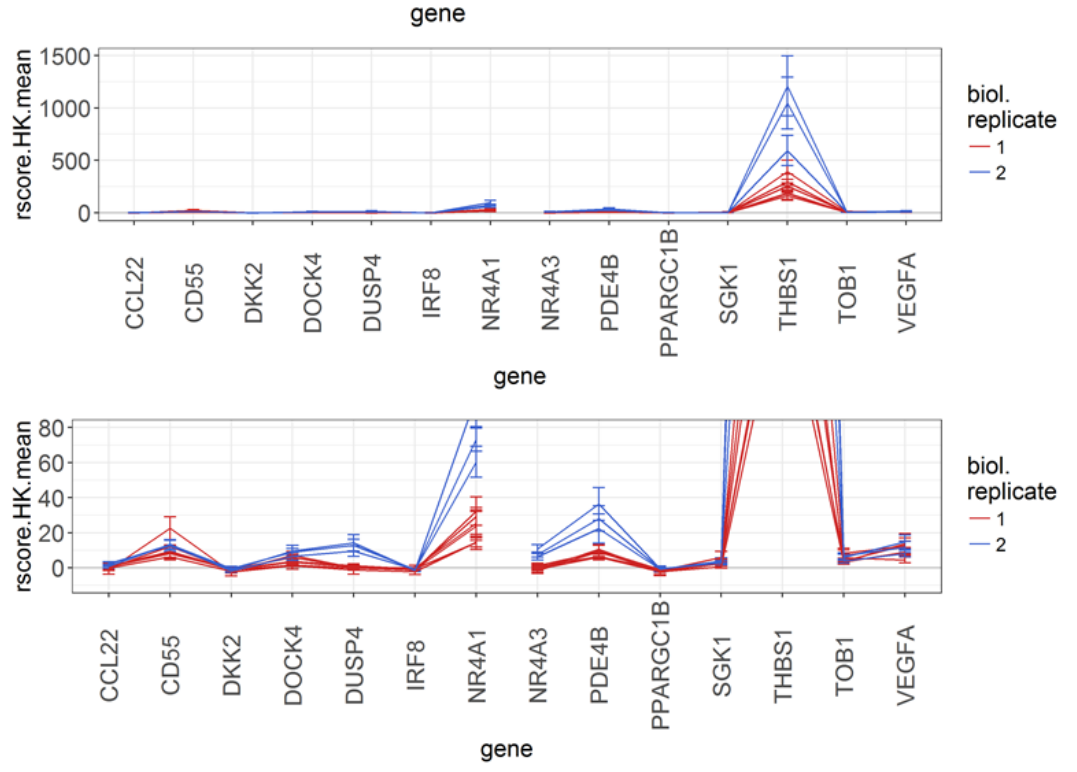

Supplementary Figure 1: Validation of the beta agonists gene-signature. a) qPCR results for DMSO, formoterol and isoproterenol demonstrate dose dependent effect on genes after $4 \mathrm{~h}$ incubation. b) QuantiGene Plex results for the two gene-signatures for $10 \mathrm{uM}$ of isoproterenol after $4 \mathrm{~h}$ incubation, shown at two different scales: upper = full scale with THBS1 having a much stronger response than the other genes, and lower $=y$-axis cut at 80 to visualize the genes with lower variance. Shown are mean standard deviations of the rscore_HK values of active control wells of each plate. 
bioRxiv preprint doi: https://doi.org/10.1101/799106; this version posted October 9 2019. The copyright holder for this preprint (which was not certified by peer review) is the author/funder, who has granted bioRxiv a license to display the preprint in perpetuity. It is made available under aCC-BY 4.0 International license.
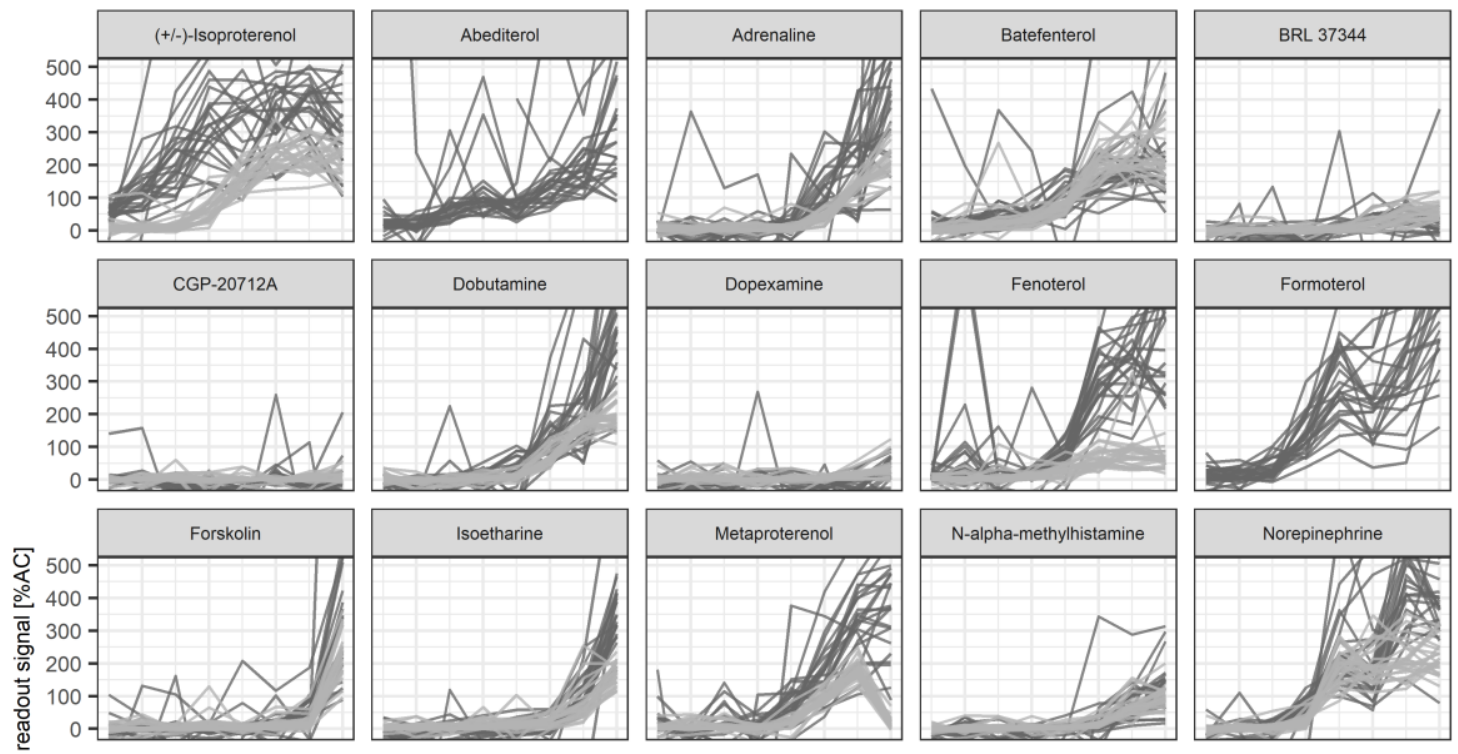

biol

replicate
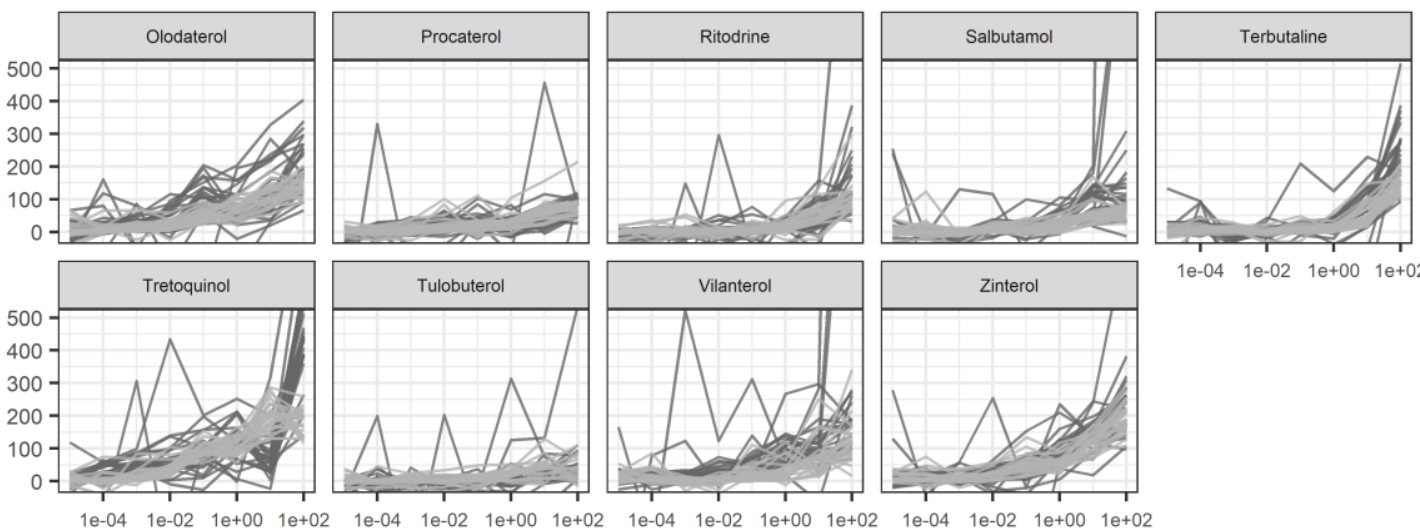

1e-04 $1 \mathrm{e}-02 \quad 1 \mathrm{e}+00 \quad 1 \mathrm{e}+02$

1

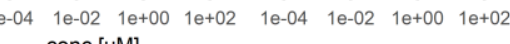

Supplementary Figure 2: Dose-response of genes for each compound in the beta agonists dataset. 
bioRxiv preprint doi: https://doi.org/10.1101/799106; this version posted October 9, 2019. The copyright holder for this preprint (which was not certified by peer review) is the author/funder, who has granted bioRxiv a license to display the preprint in perpetuity. It is made available under aCC-BY 4.0 International license.

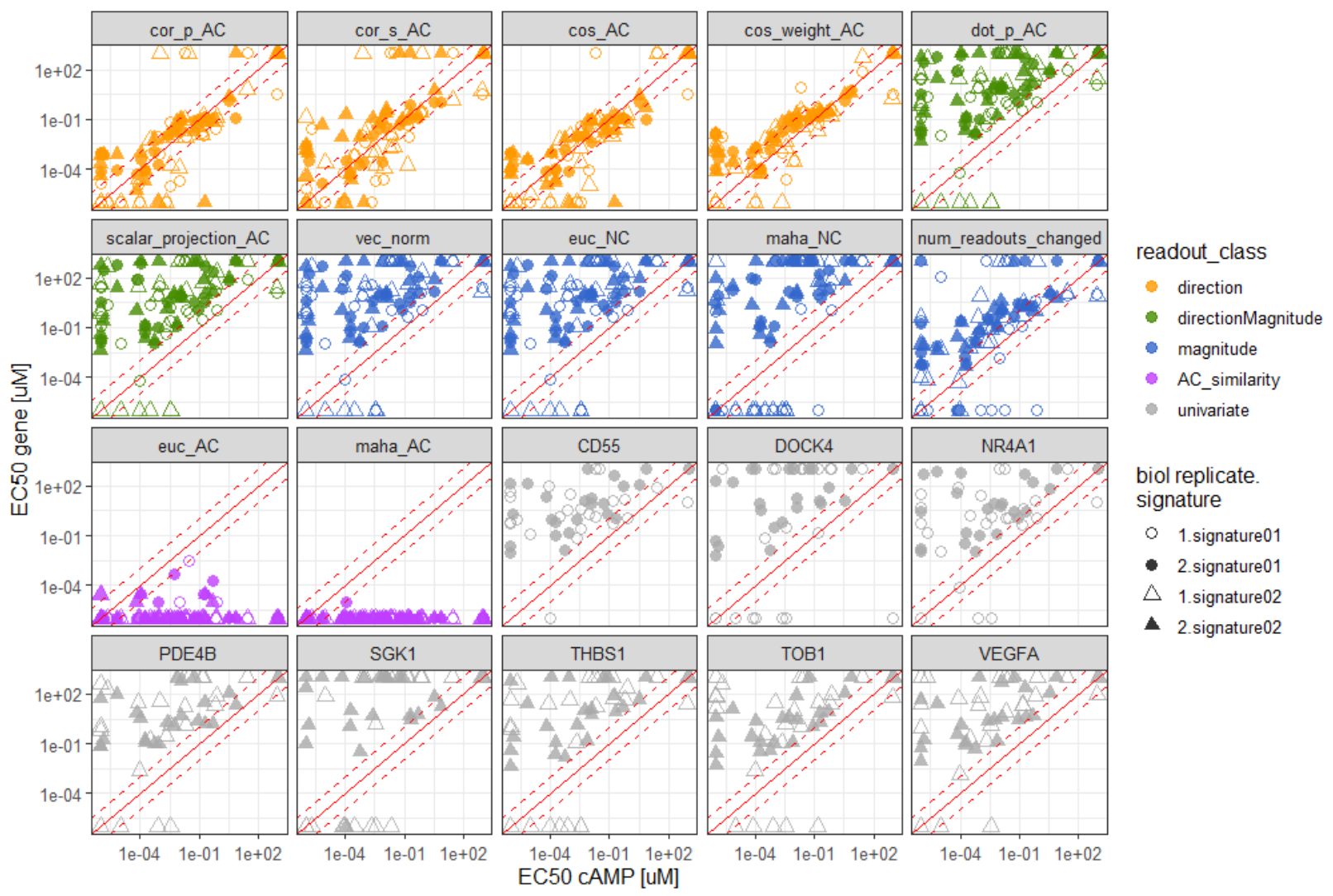

Supplementary Figure 3: Correlation of gene and gene-signature $\mathrm{EC}_{50}$ s with cAMP EC 50 s of the beta agonist dataset. 
bioRxiv preprint doi: https://doi.org/10.1101/799106; this version posted October 9, 2019. The copyright holder for this preprint (which was not certified by peer review) is the author/funder, who has granted bioRxiv a license to display the preprint in perpetuity. It is made available under aCC-BY 4.0 International license.

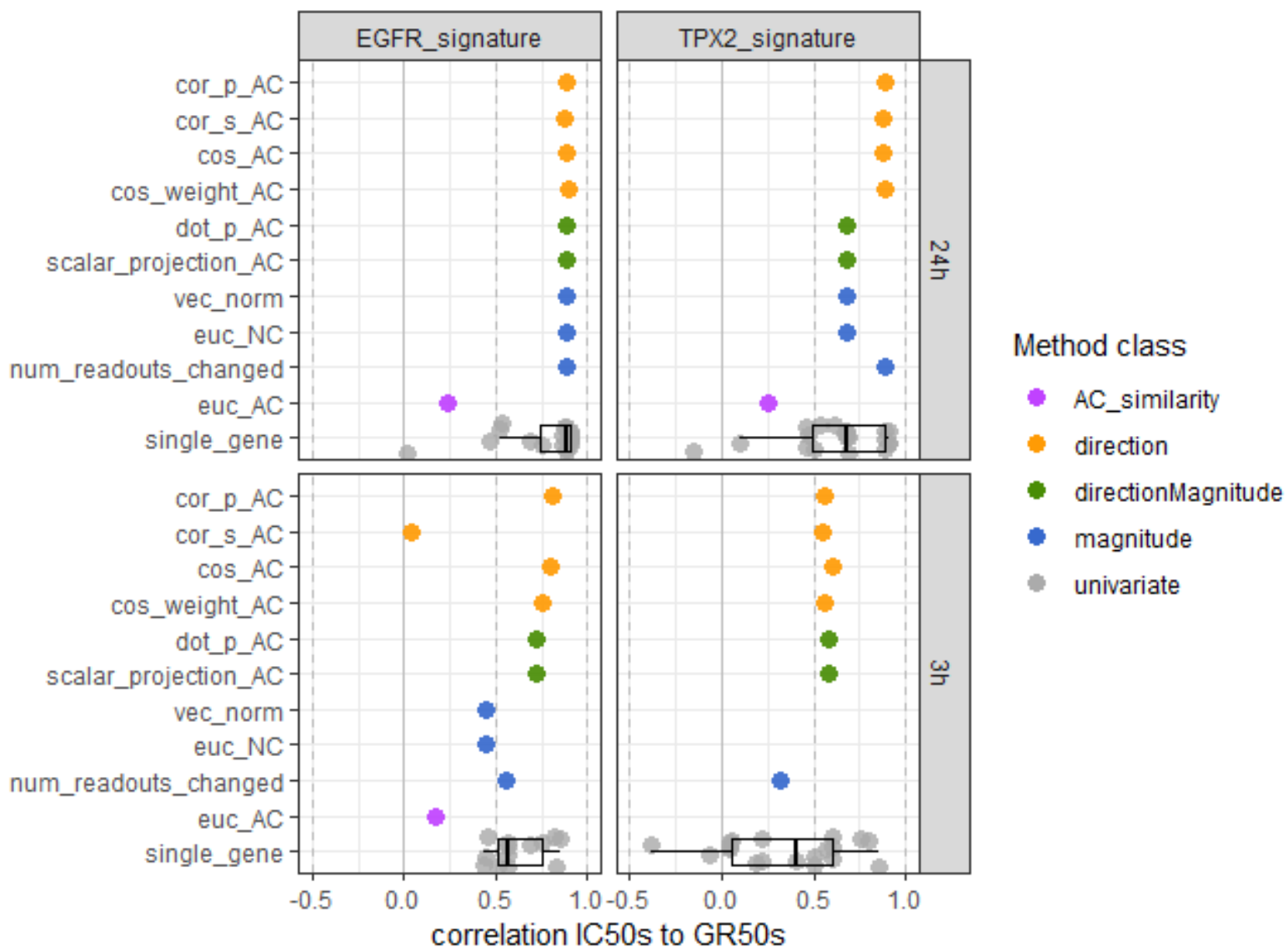

Supplementary Figure 4: Correlation of cell growth inhibition $\mathrm{GR}_{50}$ s with all gene and gene-signature $\mathrm{EC}_{50} \mathrm{~S}$ of the EGFR inhibitor dataset. 
bioRxiv preprint doi: https://doi.org/10.1101/799106; this version posted October 9 2019. The copyright holder for this preprint (which was not certified by peer review) is the author/funder, who has granted bioRxiv a license to display the preprint in perpetuity. It is made available under aCC-BY 4.0 International license.

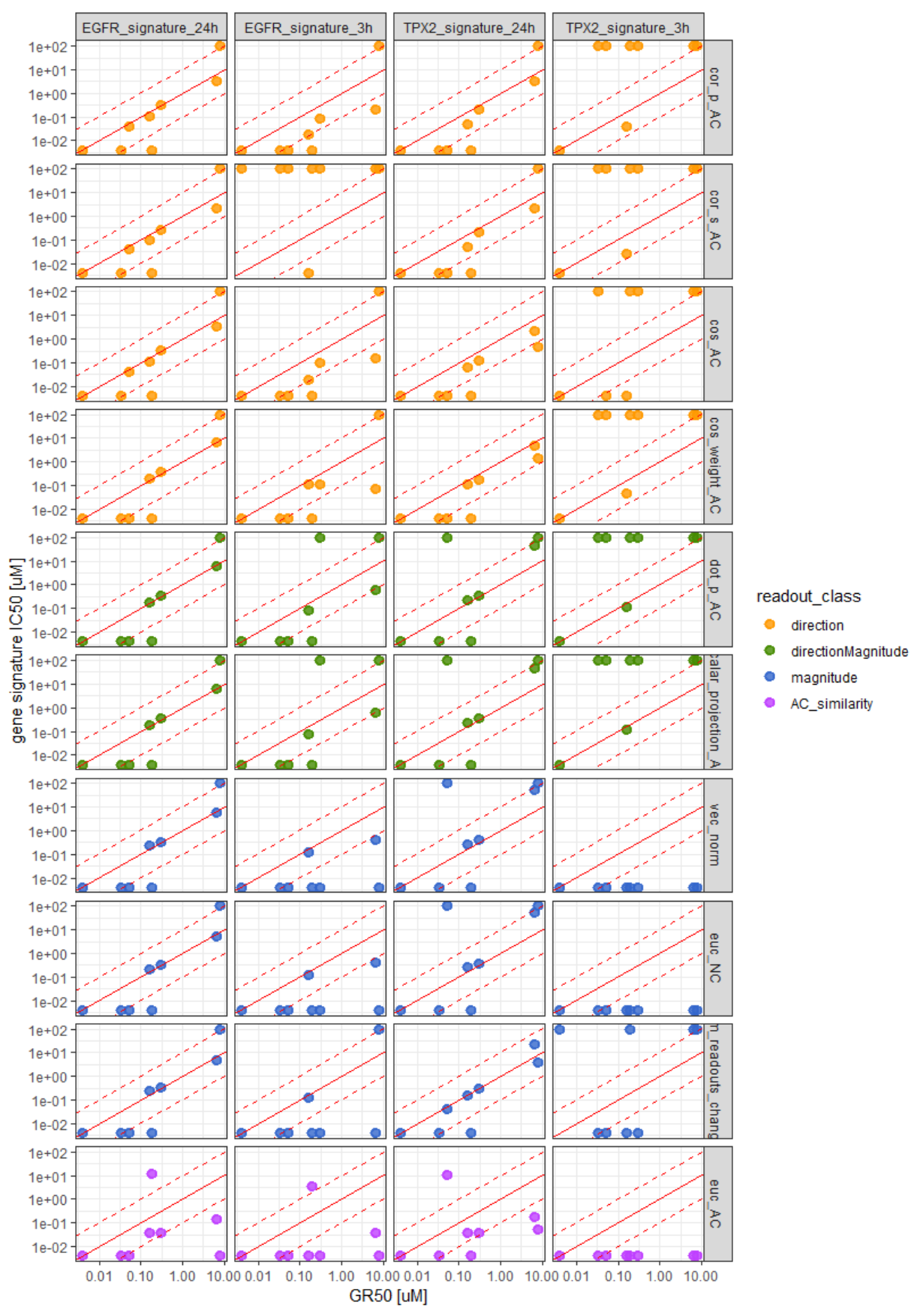

Supplementary Figure 5: Correlation of gene-signature $I_{50}$ to $\mathrm{GR}_{50}$ S of the EGFR inhibitor dataset. 
bioRxiv preprint doi: https://doi.org/10.1101/799106; this version posted October 9 , 2019. The copyright holder for this preprint (which was not certified by peer review) is the author/funder, who has granted bioRxiv a license to display the preprint in perpetuity. It is made available under aCC-BY 4.0 International license.

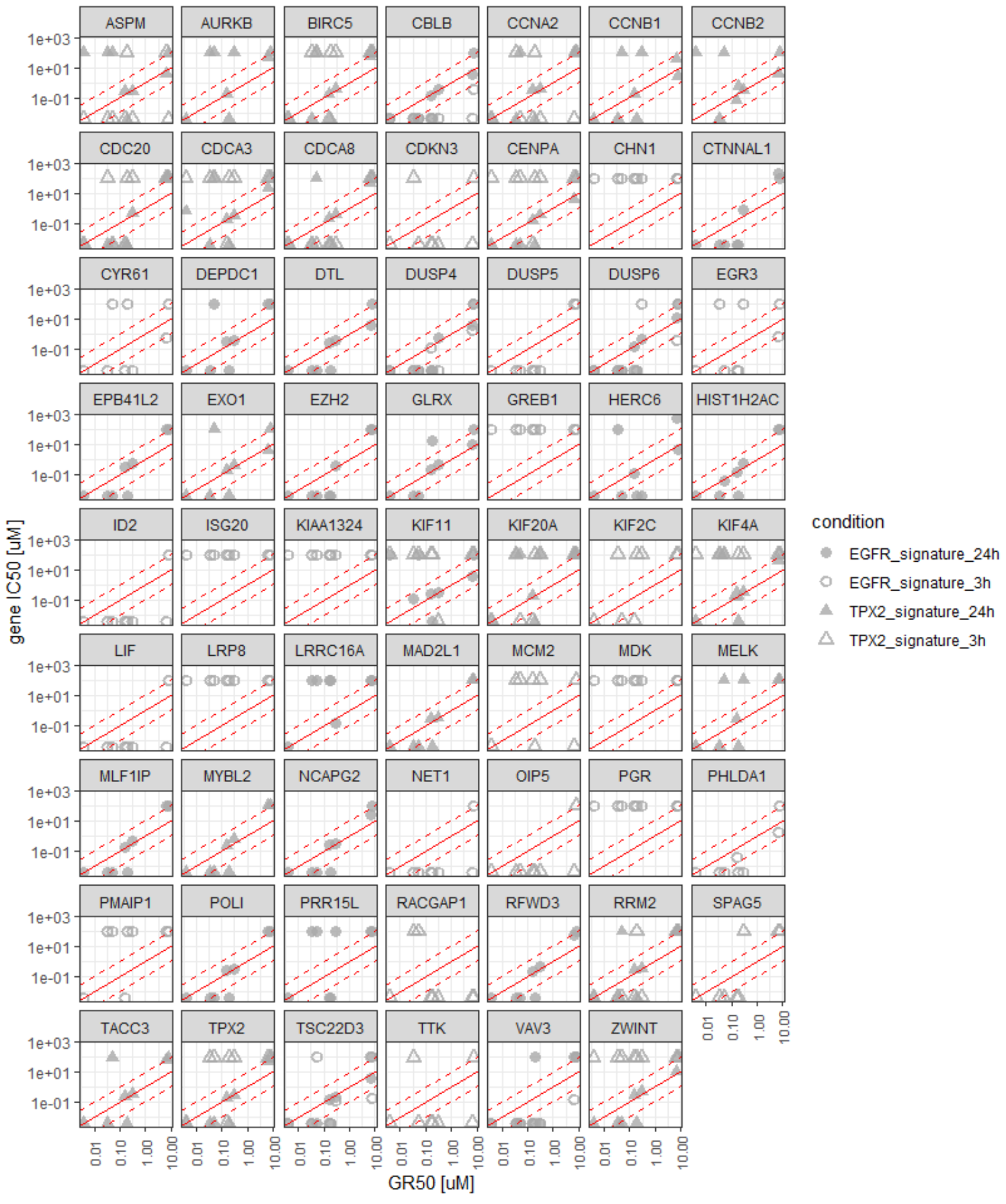

Supplementary Figure 6: Correlation of single gene $I_{50}$ to $\mathrm{GR}_{50}$ S of the EGFR inhibitor dataset, for the 20 genes most responding to the active control from the EGFR and TPX2 signatures. 